\title{
DECONCENTRATION PRACTICE AND DISINTEGRATION THREATS IN ACEH AND NORTH SUMATRA
}

\author{
Februati Trimurni \\ Faculty of Economics \& Administration \\ University of Malaya \\ Kuala Lumpur, Malaysia \\ februatitrimurni@siswa.um.edu.my
}

\begin{abstract}
Deconcentration is simply defined as the delegation of administrative authorities of the central government to the lower level of governments along with the transfer of funds to finance the implementation of the authorities. Deconcentration, in the perspective of public administration, is the transfer of administrative responsibility for specified functions to lower levels within the central government bureaucracy, generally on some spatial basis (Ferguson and Chandrasekharan, 2004). The policy and important decision still lays on the central government and the lower governments or units are merely the implementer of the policy and decision. The practice of the deconcentration in Indonesia has obviously been implementing since the independence of the country with some dynamism and adjustments particularly with the national interest, strategies, economic or even politic.
\end{abstract}

The political reform of Indonesia in the year of 1998 is mainly generated by the demands of some provinces and regions to separate from the country for instance those of demands from Aceh, Papua and Maluku. To respond the demands, central government issued decentralization law notably by the Law No.22/1999 which the revision to the previous Law No.5/1974. For some provinces which are Aceh, Jakarta, Yogyakarta and Papua, the central government issued special laws which are different to the rest provinces in the country. Yet, deconcentration principle is totally the same while the scheme of the deconcentration is bit different. An expert states one aim of practicing deconcentration in the decentralization system is to maintain the state unity and to avoid the state disintegration. This paper subsequently tries to portray the relevancy between the deconcentration practices and the state disintegration in the province of Aceh and North Sumatra.

Keywords - deconcentration;disintegration; decentralization and special autonomous region.

\section{INTRODUCTION}

Discussing on deconcentration is not apart form the discussion of decentralization which is the concept of delegating, handling over, transfer and dividing some governmental sectors authorities from the higher to the lower level of governmental structures. The definition of the decentralization itself, up to right now, has been always debatable whether on the conception, policy and the implementation on governance. The debate on the meaning of decentralization is not limited only on the terminology yet the mean of the decentralization as well (Mawhood, 1983; Rondinelli \& Chema, 1983; Davey, 1989). The decentralization concept is generally divided into political (devolution) and administrative decentralization (deconcentration). Devolution talks much on the placement of some governmental authorities on public services including of programs planning, implementation, monitoring and evaluation as well as policies from the higher level to be the autonomous and independent right of lower government. Deconcentration is more likely the transfer of some authorities of higher level government to the lower one without replacing the authorities to be the autonomous and independent right of lower government. Maddick (1963) states "deconcentration is the delegation of power to implement the special function to the central government official stationed out of the central office". The distinction of both concept is simply concluded that devolution is the permanent transfer of authorities to be autonomous right while the deconcentration is a temporary transfer of authorities to be non-autonomous right of the recipient.

The decentralization practices in Indonesia as well as those adopted through legal system is the concept of political decentralization or devolution and the concept of administrative decentralization or deconcentration. The first form of the decentralization is always called as decentralization only while the second form is called into deconcentration and co-administration. Decentralisation meant as the transfer of governments authorities to the local government and those become the genuine authorities of the local governments while the deconcentration is meant as the the transfer of governments authorities to the local government yet those are not being the the genuine authorities of the local government.

The concept of local government in Indonesia has also been introducing since the colonialization era where inside the Netherland Indices consists of some local government levels. After the independence, the changes on local government 
nomenclatures and level have been implemented six times notably in the period of I (1945-1948), II (1948-1957), III (1957-1965), IV (1965-1974), V (1974-1999) and IV (1999Present). Looking back to the implementation of decentralization in Indonesia particularly after the issuance of Law No 5/1974 up to the political reformation in 1998 , the central government applied both the symmetrical and asymmetrical decentralization. Symmetrical decentralization is the lower level units in the state are allocated equal autonomy in conducting the various roles and functions that have been decentralized without regard to the physical, ethnic, cultural (Mbeya, 2012). Garcia-Mila \& McGuire in Kumorotomo (2017) defined assymetrical decentralization as the decentralized system of regional and local governments is better able to accommodate differences in tastes for public goods and services. It means the decentralization is better to adopt the specific needs and circumstance of the region. Nasution (2012) furthermore stated the asymmetric decentralization is considered to be the solution for any such distinction exists in the geographic region, financial, natural resources, etc. The assymetrical decentralization application makes five provinces which are Aceh, Jakarta, Yogyakarta, Papua and Papua Barat practice decentralization different to the rest provinces of Indonesia.

The purpose of the research is to compare the deconcentration practices within the Province of Aceh, which is again categorized as the special autonomous province along with four others, and North Sumatra which is categorized as general autonomous province along with most of provinces within the country. The paper also aims at describing the relevancy between the deconcentration practice, particularly on the healthcare sector, in both provinces and the state disintegration.

\section{RESEARCH METHOD}

The method of research is qualitative where in-depth interviews, observations, literature study are main techniques of collecting data. The informants are the public officials and citizens within both provinces who are regarded know much about the deconcentration practices in Indonesia and the provinces. Secondary data is regarded pivotal in collecting data since the development of the decentralitazion is partly indicated by the changes on the local budget availability and allocations.

\section{DECONCENTRATION PRACTICES IN INDONESIA}

In the perspective of public administration in Indonesia, deconcentration is defined as the transfer of central government authorities to local officials and units of central government in the local areas. The deconcentration practices have been obviously implementing in the country far before the political reform of the country in 1998 or before the idea of decentralization is well known. In the historical perspective, moreover, the deconcentration has been adopting since the Dutch occupation notably when Indonesia was called as "Hindia Belanda" or Netherland Hindias and was one of the Dutch's colonized states. After the country independence in
1945 up to the fall of the "old order" or under the President Soekarno administration, the deconcentration practices were also implemented. President Soeharto, as the successor of the Soekarno administration also implemented deconcentration which more-less the same to the principles of Soekarno administration. During the six periods of local government dynamism in the country, the concept and the context of deconcentration is always introduced with a bit distinction in each period. Up to the fifth period (1945-1999) the deconcentration had been strictly implementing with the stressing on the needs of local government to do authorities of central government under the strict control of the central government. The control over the implementations of the deconcentrated programs was very huge and the obligation of the local officials to implement the programs was magnificent.

Hartanti (2010) states the distinction of deconcentration practices between the era of centralization (before 1999) and decentralization (after 1999) is the fact the deconcentration during the centralization era is not more than central government rhetoric where most of the deconcentration practices are under the strict control of the central government. The strict control over the deconcentration practices brings about the less of initiatives and creativity of the officials who hold the deconcentration practices. The political reform in the year of 1998 brings about changes on the deconcentration principles and practices where there are some spaces of local and central officials in local area to takes initiatives and creativity to conduct the deconcentrated programs. It is for instance the public services on healthcare sectors where some areas of services are under the authority of the central government. The central government in this case provides only general policies and guidelines in conducting deconcentration in the field. The control of the central government on the deconcentrated program is diminished and the reporting system is not that comprehensive such as in the era of centralisation. The deconcentration means and scopes in the era of decentralization have been incrementally magnified where in the very beginning are only given to the governor. In the decentralization era these are given to governor, major/regent or even to the officials of the central government units in the local area.

The governmental sectors which are deconcentrated to the officials in the local level or central government units in the local areas are mainly the sectors which are the absolute authorities of the central governmental. According to the Local Government Law No.22/1999, Law No.32/2004 and Law No.23/2014 there are five absolute authorities of the central governmental sectors which are: foreign affairs, national defence, religion, monetary and fiscal, as well as law and justice. However, since the country adopts the unitary systems there are also authorities of both central and local government out of the five mentioned authorities such as in the sectors of healthcare, education, environment, demography, housing and so forth. Such the areas of the public sectors are furthermore called as concurrent services. The authorities of the central government on the mentioned sectors are the authorities those are regarded unable to conduct by the local government, the services are part of national strategies or interests or the 
authorities are specifically mentioned on the national constitution.

\section{ASYMMETRICAL DECENTRALIZATION PRACTISES IN INDONESIA: A CASE OF ACEH AFTER THE POLITICAL REFORM}

There are some reasons of implementing the asymmetrical decentralization in the country. Firstly, the need to protect a long traditional culture and governance in the local area that is regarded better to be maintained such as the of sultanate system in the Province of Yogyakarta. The sultanate in the province is historically regarded giving contributions to the integration and unification of the country as a nation state. Secondly, the need of the country to place one of the provinces to be located as the capital city of the country where it is must specifically designed to accommodate the national interests as well as the needs of international agencies to represent their offices and agencies in the country. This second reason is the main idea of placing the province of Jakarta as a special autonomous province. Thirdly, the needs to accommodate local demands and maintaining the national integration. The demand of some areas such as Aceh, Maluku and Papua to get independence before and after the political reform in 1998 is a reason behind the policy of placing Aceh and Papua as the special autonomous region. Up to the present, there are five special autonomous provinces in Indonesia which are the Province of Aceh, Jakarta, Yogyakarta, Papua and Papua Barat.

Aceh as early mentioned is one of the five provinces that implement the special autonomy. The issuance of Aceh as the special autonomous province is mainly based on the demands of the civilians to (i) implement Islamic Law or Syariah within the province and (ii) the need of financial balance reform between the central government and local government. Aceh traditionally was the first Islamic sultanate in the country that showed though struggles to get the colonials out of the country which is at the time so called nusantara. Moreover, the people of the province also gave meaningful supports to the central government after the independence for instance by collecting money and gold to buy aircraft for the transportation of the President Soekarno. The province was also abandoned with rich natural resources such as natural gas and other mines where most of the profits and economic potentials went to the central government. The civilians of Aceh felt the country didn't'pay much attention to the development of Aceh after the independence and the province used to be under developed province.

Looking back to the history of the province in terms of struggle for the independence, natural resources as well as the less attention of the central government on developing the province the civilians demanded independence and built separates organization which was the Aceh Free Movement (GAM) in 1974. They had been struggling for independence, consolidated the movement and opened up the issue of independence in international forums. The bilateral and multilateral meetings of the Indonesian government and the GAM used to hold facilitated by other countries. At the end, the negotiation between the representatives of Aceh Movement and Indonesian government was reached up fruitful result by and $\mathrm{MoU}$ in 2006 where the province is still part of the country and would be allocated as the special autonomous region in the country. To formalise the MoU between the two parties, the Indonesian government issued Law No. 11/2006 on the Government of Aceh which is applied up to the right now.

\section{DECENTRALIZATION PRACTICES IN THE PROVINCE OF NORTH SUMATRA}

North Sumatra is one of provinces in the country that implements symmetrical decentralization. Like other 29 provinces, the decentralization practice runs smoothly in the province for instance the non-existence of independence demands like those in Aceh. Non-existence of such demands is also based on the history that the province feel the scheme of the decentralization is relatively accepted, the inemergence of separatist organization within the province as well as the natural resources within the province is not that potential comparing to other provinces that apply assymetrical decentralization. The province is also categorized as one of the most heterogeneous province in the country in term of social, cultural, religious and economical lives. In the political point of view, the situation at least brings difficulties to demand such independence since the people and community has a loose relation each others.

The dynamics of decentralization in the province are dominantly related to the issues of building a new local government within the province particularly occurred in the potential area in term of economic, the wide geographical area as well as the revitalisation and the re-existence of the traditional governmental and local government existed during the colonialization era. Before the year of 1998, the number of local government at district or municipal government was only 19 while after the year the province increased Up to 33. After the year of 1998, it is concluded, there are 14 new districts or municipalities built in the province. Moreover, the issues of creating new province within the original provinces have been in place since the era of decentralization up to right now.

TABLE I. POTRAY OF NEW DISTRICT/MUNICIPALITY IN THE PROVINCE OF NORTH SUMATRA AFTER THE DECENTRALIZATION ERA

\begin{tabular}{|c|c|c|c|}
\hline No & Original & $\begin{array}{l}\text { New Built Local } \\
\text { Government }\end{array}$ & $\begin{array}{c}\text { Liquided } \\
\text { /Promoted } \\
\text { Local } \\
\text { Government } \\
\end{array}$ \\
\hline $\mathrm{I}$ & $\begin{array}{l}\text { Tapanuli } \\
\text { Selatan }\end{array}$ & $\begin{array}{l}\text { 1. Mandailing Natal } \\
\text { 2.Padang Lawas } \\
\text { 3.Padang Lawas Utara }\end{array}$ & $\begin{array}{l}\text { Kotif Padang } \\
\text { Sidempuan } \\
\text { (Promoted) }\end{array}$ \\
\hline II & $\begin{array}{l}\text { Tapanuli } \\
\text { Utara }\end{array}$ & $\begin{array}{l}\text { 1. Toba Samosir } \\
\text { 2. Samosir } \\
\text { 3. Humbang Hasundutan } \\
\end{array}$ & - \\
\hline III & $\begin{array}{l}\text { Labuhan } \\
\text { Batu }\end{array}$ & $\begin{array}{l}\text { 1. Labuhan Batu Utara } \\
\text { 2. Labuhan Batu Selatan }\end{array}$ & $\begin{array}{l}\text { Kotif Rantau } \\
\text { Parapat } \\
\text { (Liquided/ } \\
\text { Closed) }\end{array}$ \\
\hline IV & Asahan & 1. Batubara & $\begin{array}{l}\text { Kotif Kisaran } \\
\text { (Liquided) }\end{array}$ \\
\hline $\mathrm{V}$ & $\begin{array}{l}\text { Deli } \\
\text { Serdang }\end{array}$ & 1. Serdang Bedagai & - \\
\hline
\end{tabular}




\begin{tabular}{|l|l|l|c|}
\hline No & Original & \multicolumn{1}{|c|}{$\begin{array}{c}\text { New Built Local } \\
\text { Government }\end{array}$} & $\begin{array}{c}\text { Liquided } \\
\text { /Promoted } \\
\text { Local } \\
\text { Government }\end{array}$ \\
\hline VI & Dairi & 1.Pak-Pak Bharat & - \\
\hline VII & Nias & $\begin{array}{l}\text { 1. Kota Gunung Sitoli } \\
\text { 2. Nias Utara } \\
\text { 3. Nias Selatan } \\
\text { 4. Nias Barat }\end{array}$ & - \\
\hline & Total & 15 & 3 \\
\hline
\end{tabular}

Source: Ministry of Interior/ Internal Affairs (2017)

\section{THE DISTINCTIONS OF DECONCENTRATION PRACTICES: A CASE ON HEALTHCARE SERVICES}

The distinction between the deconcentration practice in the Province of Aceh and North Sumatra can be traced through the decentralization practices within both provinces. Aceh applies the asymmetrical decentralization while North Sumatra applies the symmetrical decentralization. It brings on our mind there are some local authorities owned by the province of Aceh those are not-owned by the province of North Sumatra. According to the Law No 11/2006 the distinction of deconcentration practices between the two provinces are explained as follows.

Firstly, Aceh has authorities to conduct Islamic laws within the provinces. The Islamic laws allow the local government to take policies to ensure the Islamic principles are obeyed by individual citizens living in the region. The local government is also able to allocate budget for the Islamic law programs on annual local budget. Secondly, the central government put annual budget on Aceh deconcentration and decentralization so called special autonomy fund. The fund is quite big which is as much as $2 \%$ of total national general allocation fun throughout the country. In addition, the proportion and the percentage of the balance fund between the province of Aceh and the central government is bigger comparing to other non special autonomous provinces in the country. Thirdly, the intervention of central government on local government affairs is smaller than other provinces within the country.

In the context of healthcare service, there are no distinctions between the healthcare deconcentrated programs in the province of North Sumatra and those of program the province of Aceh. It is caused by the fact the healthcare sector is not a sector included either to be absolute authority of the central government or the sector that is totally delegated to the local government such as the province of Aceh. The deconcentrated programs in both provinces are some times different each year. In the year of 2015 , for instance, there are five deconcentrated programs in each province in Indonesia which are: (i) Management Support and Technical Implementation, (ii) Companionship on maternal and Child Nutrition, (iii) Development of Health Effort, (iv) Controlling of disease and Environmental Restructuring and (v) Pharmacy and Health Utilities. In 2017, there are seven scopes of deconcentrated program as described in the Table II.
TABLE II. ALLOCATED BUDGET ON DECONCENTRATED PROGRAMS OF HEALTHCARE IN 2017

\begin{tabular}{|c|l|l|l|}
\hline No & Scope of Program & \multicolumn{2}{|c|}{ In: IDR.0 Province } \\
\cline { 3 - 4 } & & North Sumatra & \multicolumn{1}{c|}{ Aceh } \\
\hline 1. & $\begin{array}{l}\text { Management Support } \\
\text { and Other Technical } \\
\text { Activities }\end{array}$ & $2,514,253,000$ & $2,127,544,000$ \\
\hline 2. & $\begin{array}{l}\text { Enhancement of } \\
\text { National Healthcare } \\
\text { Insurance }\end{array}$ & $1,579,628,000$ & $1,059,305,000$ \\
\hline 3. & $\begin{array}{l}\text { Development and } \\
\text { Capacity Building of } \\
\text { Healthcare Officials }\end{array}$ & $6,426,495,000$ & $4,739,790,000$ \\
\hline 4. & $\begin{array}{l}\text { Pharmacy and Health } \\
\text { Utilities }\end{array}$ & $1,419,083,000$ & $1,035,837,000$ \\
\hline 5. & Community Health & $39,837,378,000$ & $21,390,346,000$ \\
\hline 6. & $\begin{array}{l}\text { Prevention and } \\
\text { Controlling Over }\end{array}$ & $8,994,466,000$ & $7,925,697,000$ \\
\hline 7. & Health Services & $4,131,211,000$ & $3,019,603,000$ \\
\hline & Total & $64,902,514,000$ & $41,298,122,000$ \\
\hline
\end{tabular}

Source: Regulation of Minister of Finance No.78/2016 on The Allocation of deconcentrated Fund on Healthcare Service, http://hukor.kemkes.go.id

The distinction of design and implemented deconcentrated programs between the two province is only the fact the amount of deconcentrated budget on the healthace sector are different where the province of North Sumatra is bigger than of the province of Aceh. Yet, the amount of the budget is mainly based on the number of population in the province as well as the wide or the geographical landscape of each region.

The other distinction in the context of public healthcare service is the flexibility and the potentials of the province of Aceh to allocate more budget out of the genuine income of the provinces and the shared budget from the central government as other provinces possess it as well. The potential budget is so called the special autonomy fund which is the amount is calculated as much as $2 \%$ of the total of National General Allocation Fund. In 2017, Aceh get IDR 8 trillion which is more than a half of total annual budget of the province.

TABLE III. SCHEME OF BALANCE FUND BETWEEN CENTRAL AND LOCAL GOVERNMENT

\begin{tabular}{|c|c|c|c|c|c|}
\hline \multirow{2}{*}{$\begin{array}{c}\text { Source of } \\
\text { Balance } \\
\text { Fund }\end{array}$} & \multirow[t]{2}{*}{ Component } & \multicolumn{2}{|c|}{ North Sumatra } & \multicolumn{2}{|c|}{ Aceh } \\
\hline & & PR)* & $\mathbf{R} / \mathbf{M})^{*}$ & $\mathbf{P}$ & $\mathbf{R} / \mathbf{M}$ \\
\hline \multirow[t]{3}{*}{ Tax } & $\begin{array}{l}\text { 1. Land and } \\
\text { Building Tax }\end{array}$ & $16 \%$ & $64.8 \%$ & \multicolumn{2}{|c|}{$90 \%$} \\
\hline & \begin{tabular}{|l|} 
2. Duties on Land \\
and Building \\
Transfer
\end{tabular} & $16 \%$ & $64 \%$ & \multicolumn{2}{|c|}{$80 \%$} \\
\hline & 3. Income Tax & \multicolumn{2}{|c|}{$20 \%$} & \multicolumn{2}{|c|}{$20 \%$} \\
\hline \multirow{5}{*}{$\begin{array}{c}\text { Natural } \\
\text { Resources }\end{array}$} & 1. Forestry & \multicolumn{2}{|c|}{$80 \%$} & \multicolumn{2}{|c|}{$80 \%$} \\
\hline & 2. General Mining & \multicolumn{2}{|c|}{$80 \%$} & \multicolumn{2}{|c|}{$80 \%$} \\
\hline & 3. Fishery & \multicolumn{2}{|c|}{$80 \%$} & \multicolumn{2}{|c|}{$80 \%$} \\
\hline & $\begin{array}{l}\text { 4. Crude Oil } \\
\text { Mining }\end{array}$ & \multicolumn{2}{|c|}{$15,5 \%$} & \multicolumn{2}{|c|}{$15 \%$} \\
\hline & $\begin{array}{l}\text { 5. Natural Gas } \\
\text { Mining }\end{array}$ & \multicolumn{2}{|c|}{$30,5 \%$} & \multicolumn{2}{|c|}{$30 \%$} \\
\hline
\end{tabular}




\begin{tabular}{|c|c|c|c|c|c|}
\hline \multirow{3}{*}{$\begin{array}{c}\text { Source of } \\
\text { Balance } \\
\text { Fund }\end{array}$} & \multirow[t]{2}{*}{ Component } & \multicolumn{2}{|c|}{ North Sumatra } & \multicolumn{2}{|c|}{ Aceh } \\
\hline & & PR)* & $\mathbf{R} / \mathbf{M})^{*}$ & $\mathbf{P}$ & $\mathbf{R} / \mathbf{M}$ \\
\hline & $\begin{array}{l}\text { 6. Geothermal } \\
\text { Mining }\end{array}$ & \multicolumn{2}{|c|}{$80 \%$} & \multicolumn{2}{|c|}{$80 \%$} \\
\hline $\begin{array}{l}\text { Allocation } \\
\text { on Special } \\
\text { Autonomy }\end{array}$ & $\begin{array}{l}\text { Special } \\
\text { Autonomy } \\
\text { Fund }\end{array}$ & \multicolumn{2}{|r|}{ - } & \multicolumn{2}{|c|}{$\begin{array}{c}2 \% \text { of the } \\
\text { total of } \\
\text { National } \\
\text { General } \\
\text { Allocation } \\
\text { Fund }\end{array}$} \\
\hline
\end{tabular}

Source: Adopted from Law No 33/2004 on Financial Balance Between The Central and Local Government \& Law No UU No 11/2006 on The Government of Aceh.

)*PR= Province, $\mathrm{R} / \mathrm{M}=$ Regency/Muncipality

The deconcentration programs in the province of Aceh is less than of deconcentrated programs in the province of North Sumatra. Since the public services on religious sector is under the autonomous authority of Aceh, the central government has only very limited authorities in the province of Aceh. The authorities of the central government on the sector are limitated only on supporting the officials and training for the public official working for the local office in charges on religious sector. The deconcentrated program in the province are limited on (i) foreign affairs, (ii) national defence, (iii) monetary and fiscal, and (iv) law and justice. About the financial sector, there must be financial support from the central government to implement the decentralization of Aceh as special province.

The deconcentrated programs in the province of North Sumatra are the same to other non special provinces in the country which are the public service in the area of foreign affairs, national defence, religion, monetary and fiscal, and law and justice. The religious sector is still under the authority of the central government.

\section{THE RELEVANCY BETWEEN THE DECONCENTRATION PRACTICES AND THE STATE DISINTEGRATION}

According to local government law, all local governments have their own autonomous authorities on most sectors of governances. Yet, the central government still has own authorities which are so called absolute governmental sectors in the geographical area of local government. The local government also have their own sources of annual income which are generally classified into local tax or levies, financial balance, local royalty and miscellaneous income. In the context of asymmetrical decentralization as described above, Aceh is one of five provinces that applies special autonomy in Indonesia. The consequences of this is the fact the province of Aceh applies local governance that is difference to other provinces such as North Sumatra. According to local government law, all local governments have their own autonomous authorities on most sectors of governances. Yet, the central governmant still has own autorities which are so called absolute governmental sectors in the geographical area of local government. The local government also have their own sources of annual income which are generally classified into local tax or levies, financial balance, local royalty and miscellenous income. In the context of asymmetrical decentralization as described above, Aceh is one of five provinces that applies special autonomy in Indonesia. The concequences of this is the fact the province of Aceh applies local governance that is difference to other provinces such as North Sumatra.

TABLE IV. THE DIFFERENCE OF LOCAL INCOME BETWEEN THE PROVINCE OF NORTH SUMATRA AND ACEH IN 2017 (In

\begin{tabular}{|c|l|c|c|}
\hline \multicolumn{4}{|c|}{ IDR Million) } \\
\hline No & \multicolumn{1}{|c|}{ Descriptions } & \multicolumn{1}{c|}{$\begin{array}{c}\text { North } \\
\text { Sumatra }\end{array}$} & \\
\hline 1. & Income & 12.170 .582 & 14.291 .939 \\
\hline 2. & Genuine Income & 4.925 .627 & 2.227 .055 \\
\hline 3. & $\begin{array}{l}\text { Financial Balance Transfer } \\
\text { From Central Government }\end{array}$ & 7.235 .420 & 3.741 .189 \\
\hline 4. & Special Autonomy Fund & - & 8.303 .621 \\
\hline 5. & Number of Population & 14 & 5,01 \\
\hline 6. & Length of Area & $72.981 \mathrm{M} 2$ & 58.377 M2 \\
\hline 7. & $\begin{array}{l}\text { Ratio of Regional } \\
\text { Income/Population }\end{array}$ & 0,8 & 2.3 \\
\hline 8. & $\begin{array}{l}\text { Ratio of Regional } \\
\text { Income/Square Meter }\end{array}$ & 166 & 208 \\
\hline 9. & Poor People & 1,4 & 0.82 .610 \\
\hline
\end{tabular}

The relevancies between the deconcentration program and state disintegration can be traced back by the delegation of some central government authorities to local government. As above mentioned, the province of Aceh demanded an independence since they feel that Aceh is traditionally applied Islamic law and the citizen of the province are mostly Moslem. They also feel that the province abandoned with natural resources where the profits went to the central government account. Delegating all governmental service to the province government in the context of unitary state is impossible. The deconcentration program is regarded to diminish the state disintegration where the central government still has authorities in the local area.

\section{VIII.CONCLUSION}

There are distinctions of deconcentration practices between the province of North Sumatra and Aceh particularly the authorities of Aceh to manage the government under the Islamic law where the North Sumatra province manage the government based on the local government laws which are the same to other non-asymmetrical province through out the country. The public service as well as the authority on the healthcare sectors are principly the same yet there are more space for Aceh to use more budgets since they have another government sources of funds such as the autonomous fund as well as the bigger allocation of central-local finance balance from the central government. The practices of deconcentrated programs such as the healthcare program in Aceh is regarded pivotal to make the central government able to monitor and evaluate the province still work under the frame of the state integration. Thus, in the context of political perspective, the deconcentrated program implemented by the central government in the province of Aceh and North Sumatra is aimed at diminishing the state disintegration. 


\section{REFERENCES}

[1] Central Bureau of Statistic, "Aceh in Figures", Central Bureau of Statistic, Banda Aceh, Indonesia, 2017.

[2] Central Bureau of Statistic, "North Sumatra in Figures", Central Bureau of Statistic, Medan, Indonesia, 2017

[3] Kumorotomo, Wahyudi "Asymmetric Decentralisation: Indonesian Experience" Master in Public Administration Programme Gadjah Mada University Workshop on Functional Assignments Jakarta, 2017. http://kumoro.staff.ugm.ac.id/file_artikel/Asymmetric Decentralization, Indonesian Experience.pdf

[4] Maddick, Henry, "Democracy, DecentDecentralisationevelopment". Asia Publishing House. India, 1963.

[5] Mahwood, Philip, DecentDecentralisationConcept and the Practice, In Local Government in the Third World", Edited by Mawhood, Philip. John Wiley \& Sons Ltd. Chichester, New York, Brisbane, Toronto, Singapore, (1983)

[6] Mbeya, J "'Unity and diversity in symmetrical decentralization," Working paper, Institute of Federalism, 2012

[7] Ministry of Finance, "Laporan Realisasi Dana Perimbangan Per April 2017" (The Realization of Financial Balance Between Central and Local GovernGovernmentril 2017), Ministry of Finance,“ Direktorat Jenderal Perimbangan Keuangan, Jakarta, 2017.

[8] Ministry of Interior/ Internal Affairs, Perkembangan Daerah Otonom di Indonesia," Kementerian Dalam Negeri, 2017

[9] Nasution, Indra Kesuma, "The Challenge of DecentDecentralisationdonesia: Symmetrical and Asymmetrical Debate", International Journal of Social Science and Humanity, Vol. 6, No. 9, September 2016 pp. 691.

[10] Rondinelli, Dennis A., Nellis, John R., Cheema G. Shabbir, DecentDecentralisationveloping Countries". A Review of Recent Experience. World Bank Staff Working Papers Number 581. Management and Development Series Number 8. The World Bank Washington, D.C. USA, 1984

[11] Law No 22/1999 on Local Government

[12] Law No 32/2004 on Local Government

[13] Law No 33/2004 on Financial Balance Between Central and Local Government

[14] Law No 23/2014 on Local Government

[15] Law No 11/2006 on the Government of Aceh 